\title{
Orofaciodigital syndrome type 6
}

INSERM

\section{Source}

INSERM. (1999). Orphanet: an online rare disease and orphan drug data base.

Orofaciodigital syndrome type 6. ORPHA:2754

Joubert syndrome with orofaciodigital defect (or oral-facial-dig ital syndrome type 6 ,

OFD6) is a very rare subtype of Joubert syndrome and related disorders (JSRD, see this term) characterized by the neurological features of JS associated with orofacial anomalies and often polydactyly. 